\title{
Pattern of sexually transmitted disease in Madurai, India
}

\author{
P JEYASINGH, * T B B S V. RAMANAIAH, + AND S D FERNANDES* \\ From the *Department of STD, Government Rajaji Hospital, and the +Madurai Institute of Social Work, \\ Madurai, India
}

SUMMARY The pattern of sexually transmitted disease (STD) in a public clinic in Madurai City, India, was studied for 10 years (1974-83). Syphilis was found to be the most common STD in men $(28 \cdot 3 \%)$ and trichomoniasis in women $(39 \cdot 6 \%)$. The tropical STDs (chancroid, lymphogranuloma venereum, and granuloma inguinale) formed a sizeable proportion (30.1\%) of all STDs. A tendency to overdiagnose chancroid and lymphogranuloma venereum and a failure to detect many cases of gonorrhoea reflected a lack of laboratory facilities.

\section{Introduction}

Sexually transmitted diseases (STDs) are a global health problem of great magnitude. The pattern of STDs differs from country to country and from region to region, especially in large countries such as India. There are no accurate statistical data on the morbidity and mortality rates due to STD in India as a whole, ${ }^{1}$ although the attendance of patients with STD at the larger hospitals, particularly teaching hospitals, gives some idea of the situation. Studies of the incidence and pattern of STD in India have been few. Any study of the prevalence of these diseases that is based on hospital attendances in a locality has limited importance and value because such information neither reflects the real incidence of the diseases in the community nor permits generalisation of the data. ${ }^{2}$ We studied the pattern of STD in Madurai from 1974 to 1983 because no such attempt had been made since $1958^{2}$ and, in the words of Sir Winston Churchill, "the longer you can look back, the further you can look forward".

Madurai is an ancient city of historical importance in south India. It is also an important centre of pilgrimage for Hindus. Described as a "temple city", Madurai attracts a large number of pilgrims from different parts of the country and tourists from other states in India as well as from abroad. The city has a population of about one million.

Address for reprints: Dr $P$ Jeyasingh, Department of STD, Government Rajaji Hospital, Madurai 625020, India

Accepted for publication 20 February 1985
The STD clinic of the Government Rajaji Hospital, a teaching hospital in Madurai, was established as early as 1936 . The clinic caters for patients from the city as well as from neighbouring districts. The figure shows the staffing of the STD clinic. The average daily attendance at the clinic is $\mathbf{5 8}$ patients, which include new patients and follow up visits.

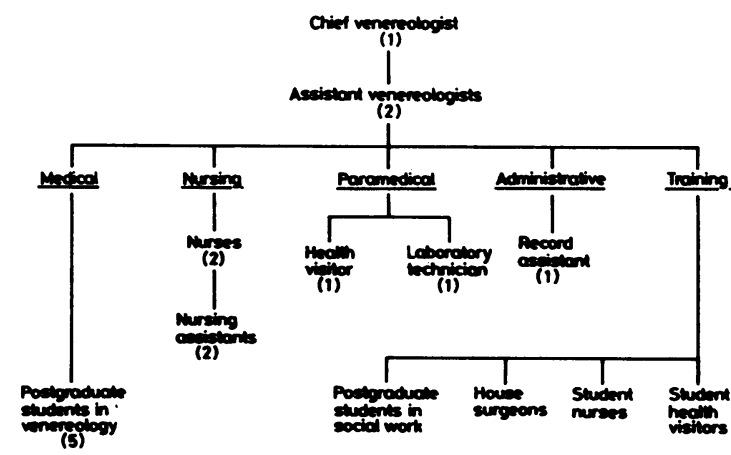

FIGURE Staffing of sexually transmitted disease clinic at the Government Rajaji Hospital, Madurai, India.

In addition to the specialists in the STD clinic, six more doctors in the city are qualified specialists in STD but do not practise the specialty full time. They are primarily general medical practitioners without an STD clinic. The number of non-specialist general practitioners who treat STD is not known. There are also a few popular quacks in the city who have established a local reputation for treating STD. 
Though the exact number of patients who are treated by such quacks is not known, it is estimated to be much higher than the number of patients attending our public STD clinic. Another STD clinic is run by the municipal corporation, but it lacks the services of a STD specialist and other amenities required for the diagnosis and treatment of STD.

\section{Patients, materials, and methods}

We studied and analysed data from the case records of patients who attended this STD clinic during the 10 years 1974-83. Diagnoses were based on the criteria shown in table I. ratio of cases of syphilis in men to women was $2 \cdot 2: 1$. The peak incidence of syphilis was seen in 1976 in both sexes. The lowest incidence was recorded in 1982 in men and in 1979 in women.

\section{Gonorrhoea}

Gonorrhoea ranked fourth of all STDs, with an incidence of $14.3 \%$ of cases of STD, $17 \cdot 8 \%$ in men and $4.5 \%$ in women. The ratio of its incidence in men to women was 10·8:1. The year 1977 recorded the peak incidence in men and the lowest incidence was found in 1979. A gradual decline in the incidence of gonorrhoea in women was seen from 1974-7, and a gradual rise has been seen since 1980 .

TABLE I Criteria for diagnosing various sexually transmitted diseases

\begin{tabular}{|c|c|}
\hline Early syphilis: & $\begin{array}{l}\text { Identification of Treponema pallidum by dark field microscopy and the Venereal Disease } \\
\text { Research Laboratory (VDRL) slide test: }\end{array}$ \\
\hline Late syphilis: & $\begin{array}{l}\text { Clinical findings and positive reactions to serological tests for syphilis (VDRL test and fluorescent } \\
\text { treponemal antibody absorbed (FTA-ABS) tests). } \\
\text { In the case of neurosyphilis, the above criteria in addition to tests on cerebrospinal fluid (CSF) } \\
\text { (cell count, biochemistry, and VDRL and FTA-ABS tests). }\end{array}$ \\
\hline Gonorrhoea: & Identification of Neisseria gonorrhoeae in Gram stained smears. \\
\hline Chancroid: & $\begin{array}{l}\text { Identification of Haemophilus ducreyi in Gram stained smears from an ulcer or bubo in some } \\
\text { cases and on clinical grounds after ruling out other ulcerative STD. }\end{array}$ \\
\hline Lymphogranuloma venereum (LGV): & On clinical grounds after excluding other STD and non-STD conditions. \\
\hline Granuloma inguinale: & Identification of calymmatobacterium granulomatis in tissue smears from the lesion. \\
\hline Herpes genitalis: & Only on clinical grounds, after exclusion of other ulcerative STD. \\
\hline Trichomoniasis: & Identification of Trichomonas vaginalis in wet films and culture in modified Diamond's medium. \\
\hline Candidiasis: & $\begin{array}{l}\text { Identification of Candida species of fungi in wet potassium hydroxide preparations and culture in } \\
\text { Sabouraud's medium. }\end{array}$ \\
\hline Genital warts: & Clinically by the morphology of the lesion. \\
\hline
\end{tabular}

Results

\section{INCIDENCE OF STD}

A total of 25119 cases of STD and a further 21583 non-STD conditions were seen during the 10 year period. Of the cases of STD, $18412(73 \cdot 3 \%)$ were in men and $6707(26.7 \%)$ in women. Of the non-STD conditions, $15041(69 \cdot 7 \%)$ were in men and 6542 $(30.3 \%)$ in women. The mean number of attendances for STD in a year was $\mathbf{1 8 4 1}$ for men and 671 for women. Table II shows the incidence of individual STDs in the whole study period, and table III shows the incidence in each year. The ratio of incidences in men to women was $2 \cdot 8: 1$, and syphilis, gonorrhoea, chancroid, lymphogranuloma venereum (LGV), and granuloma inguinale were seen in more men than women each year.

\section{Syphilis}

Syphilis was the most common STD in Madurai, with an incidence of $30.3 \%$ of all cases of STD. Although its incidence in men $(28 \cdot 3 \%)$ was greater than that of any other STD, its incidence in women $(35 \cdot 7 \%)$ was exceeded by that of trichomoniasis $(39 \cdot 6 \%)$. The
TABLE II Incidence of various sexually transmitted diseases in $1974-83$

\begin{tabular}{|c|c|c|c|}
\hline \multirow[b]{2}{*}{ Diagnosis } & \multicolumn{2}{|c|}{ No $(\%)$ of cases in } & \multirow{2}{*}{$\begin{array}{l}\begin{array}{l}\text { Total No. } 1 \% \\
\text { of cases }\end{array} \\
(n=25 \quad 119)\end{array}$} \\
\hline & $\begin{array}{l}\text { Men } \\
(n=18412)\end{array}$ & $\begin{array}{l}\text { Women } \\
(n=6707)\end{array}$ & \\
\hline \multirow{5}{*}{$\begin{array}{l}\text { Syphilis: } \\
\text { Primary } \\
\text { Secondary } \\
\text { Latent } \\
\text { Benign } \\
\text { tertiary } \\
\text { Neuro- } \\
\text { syphilis } \\
\text { Cardio- } \\
\text { vascular } \\
\text { Congenital }\end{array}$} & & & \\
\hline & $\begin{array}{l}2471(13 \cdot 42) \\
1093(5 \cdot 94) \\
1372(7 \cdot 45)\end{array}$ & $\begin{array}{r}448(6 \cdot 68) \\
808(12 \cdot 05) \\
1058(15 \cdot 77)\end{array}$ & $\begin{array}{l}2919(11 \cdot 62) \\
1901(7 \cdot 57) \\
2430(9 \cdot 67)\end{array}$ \\
\hline & $37(0 \cdot 20)$ & $14(0 \cdot 21)$ & $51(0.20)$ \\
\hline & $177(0.96)$ & $20(0 \cdot 30)$ & $197(0 \cdot 78)$ \\
\hline & $\begin{array}{rr}64 & (0.35) \\
1 & (0.01)\end{array}$ & $\begin{array}{rr}6 & (0.09) \\
39 & (0.58)\end{array}$ & $\begin{array}{ll}70 & (0 \cdot 28) \\
40 & (0 \cdot 16)\end{array}$ \\
\hline Total & $5215(28 \cdot 32)$ & $2393(35 \cdot 68)$ & $7608(30 \cdot 29)$ \\
\hline $\begin{array}{l}\text { Gonorrhoea } \\
\text { Chancroid }\end{array}$ & $\begin{array}{l}3283(17 \cdot 83) \\
3523(19 \cdot 13)\end{array}$ & $\begin{array}{l}303(4 \cdot 52) \\
347(5 \cdot 17)\end{array}$ & $\begin{array}{l}3586(14 \cdot 28) \\
3870(15 \cdot 41)\end{array}$ \\
\hline $\begin{array}{l}\text { granuloma } \\
\text { venereum } \\
\text { Granuloma }\end{array}$ & $2524(13 \cdot 71)$ & $418(6 \cdot 23)$ & $2942(11 \cdot 71)$ \\
\hline $\begin{array}{l}\text { inguinale } \\
\text { Others }\end{array}$ & $\begin{array}{r}548(2 \cdot 98) \\
3319(18 \cdot 03)\end{array}$ & $\begin{array}{c}197(2 \cdot 94) \\
3049(45 \cdot 46)^{*}\end{array}$ & $\begin{array}{r}745(2 \cdot 97) \\
6368(25 \cdot 35)\end{array}$ \\
\hline
\end{tabular}

*Including 2658 (39.63\%) women with trichomoniasis. 
TABLE III Incidence of sexually transmitted diseases in each of 10 years 1974-83

\begin{tabular}{|c|c|c|c|c|c|c|c|c|c|c|c|c|c|c|}
\hline \multirow[t]{2}{*}{ Year } & \multicolumn{2}{|c|}{ Syphilis } & \multicolumn{2}{|c|}{ Gonorrhoea } & \multicolumn{2}{|c|}{ Chancroid } & \multicolumn{2}{|c|}{$\begin{array}{l}\text { Lymphogranuloma } \\
\text { venereum }\end{array}$} & \multicolumn{2}{|c|}{$\begin{array}{l}\text { Granuloma } \\
\text { inguinale }\end{array}$} & \multicolumn{2}{|c|}{ Others } & \multicolumn{2}{|l|}{ Total } \\
\hline & Men & Women & Men & Women & Men & Women & Men & Women & Men & Woman & Men & Women & Men & Women \\
\hline 1974 & 537 & 197 & 275 & 31 & 218 & 47 & 295 & 61 & 29 & 11 & 357 & $\begin{array}{l}319 \\
293^{*}\end{array}$ & 1711 & 666 \\
\hline 1975 & 568 & 249 & 332 & 23 & 264 & 32 & 280 & 63 & 30 & 21 & 405 & $\begin{array}{l}319 \\
276^{*}\end{array}$ & 1879 & 707 \\
\hline 1976 & 687 & 322 & 330 & 15 & 294 & 22 & 241 & 57 & 28 & 15 & 343 & $\begin{array}{l}359 \\
326^{*}\end{array}$ & 1923 & 790 \\
\hline 1977 & 648 & 295 & 428 & 0 & 416 & 47 & 341 & 45 & 29 & 9 & 364 & $\begin{array}{l}329 \\
286^{*}\end{array}$ & 2226 & 725 \\
\hline 1978 & 590 & 246 & 277 & 0 & 515 & 65 & 392 & 35 & 35 & 26 & 434 & $\begin{array}{l}259 \\
218^{*}\end{array}$ & 2243 & 631 \\
\hline 1979 & 457 & 179 & 274 & 0 & 304 & 11 & 270 & 35 & 119 & 23 & 262 & $\begin{array}{l}237 \\
196^{*}\end{array}$ & 1686 & 485 \\
\hline 1980 & 476 & 244 & 348 & 22 & 382 & 22 & 143 & 40 & 139 & 19 & 354 & $\begin{array}{l}333 \\
287^{*}\end{array}$ & 1842 & 680 \\
\hline 1981 & 457 & 190 & 352 & 52 & 392 & 51 & 203 & 43 & 65 & 21 & 214 & $\begin{array}{l}240 \\
203^{*}\end{array}$ & 1683 & 597 \\
\hline 1982 & 388 & 207 & 316 & 60 & 384 & 17 & 197 & 21 & 41 & 25 & 304 & $\begin{array}{l}282 \\
258^{*}\end{array}$ & 1630 & 612 \\
\hline 1983 & 407 & 264 & 351 & 100 & 354 & 33 & 162 & 18 & 33 & 27 & 282 & $\begin{array}{l}372 \\
315^{*}\end{array}$ & 1589 & 814 \\
\hline Total & 5215 & 2393 & 3283 & 303 & 3523 & 347 & 2524 & 418 & 548 & 197 & 3319 & 3049 & 18412 & 6707 \\
\hline
\end{tabular}

*Cases of trichomoniasis.

\section{Chancroid}

Chancroid was the third most common STD, with an incidence of $15 \cdot 4 \%$ of all cases of STD, and was the second most common STD in men. Its incidence in patients with STD was $19 \cdot 1 \%$ in men and $5 \cdot 2 \%$ in women, the ratio of cases in men to women being $10 \cdot 2: 1$. The highest incidence was found in 1978 in both sexes. The lowest incidence was seen in 1974 in men and 1979 in women.

\section{Lymphogranuloma venereum (LGV)}

LGV was the cause of $11 \cdot 7 \%$ of all cases of STD, $13.7 \%$ in men and $6.2 \%$ in women with STD. The ratio of its incidence in men to women was $6: 1$. The year 1978 marked the highest incidence in men, and 1980 the lowest. In women the highest incidence was in 1975 and the lowest in 1983.

\section{Granuloma inguinale}

Granuloma inguinale was the least common STD, being $3 \%$ of cases in men and women with STD. The ratio of its incidence in men to women was $2 \cdot 8: 1$. The highest incidence in men in 1980 was followed by a steady decline, whereas a gradual rise in its incidence in women has been seen since 1980 .

\section{Other STDs}

These included trichomoniasis, candidiasis, genital warts, genital herpes, and non-gonococcal urethritis, and were found in $25.4 \%$ of all cases of STD. They accounted for $18 \%$ of cases of STD in men and as many as $45.5 \%$ in women because trichomoniasis was included in the list of other STDs. The incidence of other STDs in both sexes varied from year to year.
Trichomoniasis was the most common STD in women $(2658 / 6707(39.6 \%$ of cases of STD in women)). The incidence was highest in 1976 and lowest in 1979, although no trend was seen as the incidence rose and fell irregularly throughout the period.

\section{Discussion}

Although the population of Madurai has increased considerably in the past two decades, the yearly attendance of patients with STD has decreased, probably because of more widespread use of antibiotics, a greater number of specialists, and because of the recent emergence of some popular quacks who have established a local reputation for treating these diseases.

Many men and women who do not suffer from any STD attend the STD clinic either as a precautionary measure, having been at risk, or for other nonvenereal conditions of the genitals. The ratio of cases of STD to non-STD conditions in our study was $1 \cdot 2: 1$. In the United States, Felman also found such an increased attendance due to conditions other than STD. ${ }^{3}$

The preponderance of men with all STDs except trichomoniasis confirms the findings of Datta and Velou in Pondicherry, India, who found that more men than women presented with syphilis, gonorrhoea, chancroid, LGV, and granuloma inguinale. ${ }^{4}$ The fear of social stigma and the lack of clinical features of STD in women have been cited as probable reasons. $^{5}$

Syphilis is the most common STD in Madurai. 
This has also been found in some other states of India. ${ }^{46-8}$ Unlike in many developed countries, the incidence of syphilis is still very high in India. A high incidence of syphilis is still seen in many developing countries as the social and environmental patterns are different, control measures are poor or nonexistent, health education is impeded by illiteracy, and there are many competing priorities for the limited human and economic resources available. ${ }^{9}$ As efficient contact tracing is almost non-existent, the momentum of spread of syphilis remains unchecked.

A wide disparity between the sexes was found in the distribution of gonorrhoea and chancroid, which were almost ten times more common in men than women. The predominantly asymptomatic nature of gonorrhoea in women and lack of facilities for routine culture tests for Neisseria gonorrhoeae for all women attenders in STD clinics are the main reasons for such a low incidence of the disease in women. Whereas in many western countries a desirable trend of lowering the ratio of men to women with gonorrhoea has been seen (because of better diagnostic facilities and improved methods of contact tracing), the situation in a developing country like India has not changed over the years.

The preponderance of chancroid in men is well known. ${ }^{10} 11$ The existence of an asymptomatic carrier state in women and the possibility of only a few women transmitting the infection to a large number of men, such as through prostitution, are the probable reasons for a surprisingly lower incidence of chancroid in women. The latter may be the most important factor as prostitutes provide the predominant sexual outlet in the areas where chancroid is common. ${ }^{12}$ Chancroid was found to be the second most common infection as noted in other studies in India. ${ }^{4713}$ As Willcox pointed out, chancroid is common in conditions of poverty and poor hygiene, and where the incidence of syphilis is still high, so is that of chancroid. ${ }^{14}$ We found a higher incidence of chancroid than that reported by other workers. ${ }^{2} 15$

The incidence of LGV and granuloma inguinale was also higher than that reported by other workers in India. ${ }^{27131617}$ It is well known that granuloma inguinale is endemic in Tamil Nadu. A higher incidence of LGV was found in Madurai compared with Madras, which is in the same state (Sowmini $\mathrm{CN}$, unpublished observation), although we found a lower incidence of granuloma inguinale than that $(5 \cdot 3 \%)$ reported by Lal and Nicholas. ${ }^{18}$

The tropical STDs (chancroid, LGV, and granuloma inguinale) are more common in Madurai than in western countries, where they present a relatively insignificant problem. ${ }^{14}$ Their incidence shows an alarming rise compared with that in Madurai in $1958 .{ }^{2}$ Apart from a higher index of suspicion about tropical STDs, chancroid is possibly often overdiagnosed because confirmatory tests are not available. The same view was expressed by Arya and Lawson. ${ }^{19}$ The diagnosis of LGV is also made purely on clinical grounds in our centre, as the facilities for culture for chlamydiae and the LGV complement fixation test are not available. There is also, therefore, every chance of overdiagnosing LGV. Osoba observed that LGV is diagnosed on clinical grounds in many developing countries. ${ }^{20}$

Trichomoniasis was found to be the most common STD in women. A higher incidence of trichomoniasis in women during their years of greatest sexual activity, and in women of low socioeconomic status, is well known. ${ }^{21-23}$

We thank the head of the department of STD, Government Rajaji Hospital, Madurai, for his kind permission to carry out this study.

\section{References}

1. Rajam RV. Venereal diseases in India. British Journal of Venereal Diseases 1956; 32:79-81.

2. Ayyangar MCR. A study on the incidence and pattern of venereal diseases at Madurai. Indian Journal of Dermatology and Venerology 1959;25:139-46.

3. Felman YM. Relative incidence of sexually transmitted diseases in New York City social hygiene clinics 1977-1979. Bull NY Acad Med 1980;56:715-20.

4. Datta SP, Velou A. Trends in the prevalence of venereal diseases in Pondicherry 1961-65, part II. Indian Journal of Dermatology and Venereology 1968;34:70-6.

5. Gupta RN, Jain VC, Chandra R. Study of socio-morbid pattern at the VD out-patient department of a teaching hospital in the summer and winter seasons. Indian Journal of Dermatology and Venereology 1968;34:237-40.

6. Garg BR, Lal S. Changing pattern of sexually transmitted diseases. Indian Journal of Sexually Transmitted Diseases 1982; 3:41-2.

7. Singh R. Pattern of venereal diseases as seen at the venereal diseases training and demonstration centre, Safdarjang Hospital, New Delhi. Indian Journal of Dermatology and Venereology 1962;28:62-9.

8. Ramachander M. A study on the pattern and prevalence of venereal diseases at Kurnool. Indian Journal of Dermatology and Venereology 1960;26:155-65.

9. Harris JRW. Syphilis-epidemiological and social aspects. In Morton RS, Harris JRW, eds. Recent advances in sexually transmitted diseases. 1st ed. Edinburgh, London, and New York: Churchill Livingstone, 1975:91-6.

10. Canizares O. Dermatology. Vol. I. Philadelphia, London, and Toronto: WB Saunders, 1975.

11. Fiumara NJ. Clinical dermatology. Vol. III. Hagerstown, Maryland: Harper \& Row, 1977

12. US Public Health Service. Chancroid donovanosis, and lymphogranuloma venerum. Atlanta, Georgia: US Department of Health, Education and Welfare. DHEW publication No (CDC) 75-8302 (formerly PHS No 255).

13. Bhargava RK, Gupta BK. Pattern of STD in Jaipur, Rajasthan. Indian Journal of Sexually Transmitted Diseases 1983;4:23-5.

14. Willcox RR. Trends in the prevalence of venereal diseases in England and Wales. British Journal of Venereal Diseases 1962; 38: 189-99.

15. Nair BKH, Viswam MP, Venugopal BS, Nair PS. An epidemiological study of venereal diseases. Indian J Med Res 1973;61:1697-707.

16. Kapur TR. Pattern of sexually transmitted diseases in India. Indian Journal of Dermatology, Venereology and Leprology 1982; 48: 23-34. 
17. Rajam RV, Rangiah PN. Donovanosis. Geneva: World Health Organisation, 1954. (WHO Monograph Series No 24).

18. Lal S, Nicholas C. Epidemiological and clinical features in $\mathbf{1 6 5}$ cases of granuloma inguinale. British Journal of Venereal Diseases 1970;46:461-3.

19. Arya OP, Lawson JB. Sexually transmitted diseases in the tropics. Epidemiological, diagnostic, therapeutic, and control aspects. Trop Doct 1977; 7:51-6.

20. Osoba AO. Lymphogranuloma venereum. In: Harris JRW, ed. Recent advances in sexually transmitted diseases. 2nd ed. Edinburgh, London, Melbourne, and New York: Churchill Livingstone, 1981:211-6.
21. Morton RS. Trichomoniasis-epidemiological and social aspects. In: Morton RS, Harris JRW, eds. Recent advances in sexually transmitted diseases. 1st ed. Edinburgh, London, and New York: Churchill Livingstone, 1975:203-9.

22. Willcox RR. Epidemiological aspects of human trichomoniasis. British Journal of Venereal Diseases 1960; 36: 167-74.

23. Jeyasingh P, Prasad PVS, Ranganathan PS, Malini G. Epidemiology of trichomoniasis in Madurai. Indian Journal of Sexually Transmitted Diseases 1982;3:32-4. 